\title{
Efficacy of Exogenous Calcium Applications for Reducing Upper Leaf Necrosis in Lilium 'Star Gazer'
}

\author{
Yao-Chien Chang ${ }^{1}$ \\ Department of Horticulture, Cornell University, Ithaca, NY 14853-5904
}

Karen Grace-Martin ${ }^{2}$

Office of Statistical Consulting, Division of Nutritional Sciences, Cornell University, Ithaca, NY 14853-5904

\author{
William B. Miller ${ }^{3}$ \\ Department of Horticulture, Cornell University, Ithaca, NY 14853-5904
}

Additional index words. lily, calcium deficiency disorder, foliar calcium sprays, bulb calcium dipping, calcium nutrition, leaf scorch, tipburn

\begin{abstract}
Upper leaf necrosis (ULN) on Lilium 'Star Gazer' is a calcium deficiency disorder. In this study, we evaluated the efficacy of foliar Ca sprays and bulb Ca dipping on reducing ULN. Necrosis severity of a single leaf was determined by an index from 0 (healthy) to 5 , based on symptom progression and necrosed leaf area. Single leaf severity was then summed for all leaves to yield a whole-plant severity rating. Single daily applications of $\mathbf{2 5}$ мм calcium chloride or calcium nitrate sprays for $\mathbf{1 4}$ days significantly suppressed the degree of symptom expression; whole-plant severity was reduced from 18 (severely necrosed) to below 3 (essentially unnoticeable). Five single applications at 3.5-day intervals were not effective, even at concentrations up to $150 \mathrm{~mm}$. At concentrations of 100 and 150 mM, 14 daily sprays of calcium chloride or calcium nitrate were toxic and caused leaf tip yellowing; calcium chloride caused more severe phytotoxicity than did calcium nitrate. For effectiveness of foliar Ca sprays, it was necessary to have the Ca solution reach the enclosed, young, expanding leaves. Preplant bulb immersion in calcium chloride was not effective even at concentrations as high as $\mathbf{4 0 0} \mathrm{mm}$ for up to 16 hours.
\end{abstract}

Upper leaf necrosis (ULN) on Lilium 'Star Gazer' is a calcium deficiency disorder (Chang, 2002), as is bitter pit in apple (Malus $\times$ domestica Borkh.) (Ferguson and Watkins, 1989) and tipburn in lettuce (Lactuca sativa L.) (Collier and Tibbitts, 1982). It has been shown that there are two primary mechanisms leading to ULN. The first is a very low bulb calcium content that cannot meet $\mathrm{Ca}$ demand when the upper leaves are expanding (Chang

Received for publication 5 May 2003. Accepted for publication 23 Nov. 2003. This paper is mainly based on a PhD dissertation submitted by Y.C. Chang. Use of trade names does not imply endorsement of named products nor criticism of similar ones not named. We thank Timothy L. Setter, Leon V. Kochian, and Garry Legnani of Cornell Univ. for their sound advice on this project. This research was funded in part through a Specific Cooperative Agreement between the USDA/ARS Plant Protection Research Unit and the Cornell Dept. of Plant Pathology, Ithaca, N.Y. (SCA \# 58-1907-0-035) funded by the USDA/ARS as part of the Floriculture and Nursery Research Initiative. We gratefully acknowledge the financial and material support from the Ministry of Education, Taiwan, the Fred C. Gloeckner Foundation, the Kenneth Post-Herman Schenkel Memorial Council, and the Royal Dutch Wholesalers' Association for Flowerbulbs and Nursery Stock.

${ }^{1}$ Former Graduate Research Assistant; currently Postdoctoral Research Associate.

${ }^{2}$ Statistical Consultant.

${ }^{3}$ Professor; to whom reprint requests should be addressed. E-mail: wbm8@cornell.edu and Miller, 2003). The second is that young expanding leaves of Lilium 'Star Gazer' are highly overlapped before flower buds are visible. This leaf "enclosure" reduces transpiration of young leaves and encourages the development of ULN (Chang and Miller, 2004). As a result of these factors, necrosis commonly occurs on the upper leaves (Chang, 2002). On average, a 'Star Gazer' plant grown from a 16to 18 -cm bulb has 44 leaves. Only $\approx 15$ leaves on the top of the plant are susceptible to ULN (Chang, 2002). The susceptible period for ULN is 25-50 d after planting (Chang and Miller, 2004). ULN decreases the market value of the plant and reduces its appeal to consumers. The current industry practice is the manual removal of necrosed leaves before plants are marketed, a very labor intensive proposition.

Plants are able to absorb mineral nutrients rapidly through foliage. Foliar sprays thus have great practical utility to overcome nutrition deficiencies caused by micronutrients. However, due to the limited phloem mobility of calcium, foliar $\mathrm{Ca}$ sprays are not always effective (Marschner, 1995). Therefore, the effectiveness of foliar Ca sprays to control Ca deficiency disorders was somewhat controversial, such as for overcoming tipburn on lettuce (Collier and Tibbitts, 1982; Kruger, 1966). Nevertheless, there are reports that foliar $\mathrm{Ca}$ sprays are effective in reducing $\mathrm{Ca}$ related disorders in several crops, including tipburn in Asiatic hybrid lily (Lilium L.) 'Pirate' (Berghoef, 1986), marginal bract necrosis in poinsettia (Euphorbia pulcherrima Willd. ex Klotzsch) (Wissemeier, 1993), and bitter pit in apple fruit (Ferguson and Watkins, 1989). Effectiveness of foliar Ca sprays depends on environmental conditions. Spraying with $0.7 \%$ calcium nitrate was effective in preventing tipburn in Chinese cabbage at normal relative humidity (RH), but was not effective at higher RH (van Berkel, 1988). The most effective Ca salt concentration also varied by crop. For Asiatic lily 'Pirate,' $68 \mathrm{~mm}(1 \%)$ calcium chloride was able to reduce tipburn to an acceptable level in most cases, but in others a concentration up to $204 \mathrm{~mm}(3 \%)$ was required (Berghoef, 1986). Calcium chloride at $0.35 \%$ or $0.7 \%$ calcium hydroxide reduced rain splitting in sweet cherries (Meheriuk et al., 1991). Only $5 \mathrm{~mm}(0.07 \%)$ calcium chloride was required to reduce marginal bract necrosis on poinsettia (Wissemeier, 1993).

It has been shown that lily bulbs are able to absorb plant growth regulators (PGR). Dipping bulbs in PGR solutions for only 1 min was effective for lily height control (Ranwala et al., 2002). In apple, postharvest dips in $1 \%$ to $4 \% \mathrm{Ca}$ salt solutions are effective for reducing bitter pit (Ferguson and Watkins, 1989). In contrast, soaking lily bulbs for $24 \mathrm{~h}$ in 136 $\mathrm{mm}(2 \%)$ or $272 \mathrm{~mm}(4 \%)$ calcium chloride did not reduce tipburn on Asiatic hybrid lily 'Pirate' (Berghoef, 1986).

Given the paucity of data on calcium absorption and distribution in bulbous crops, and on the role of $\mathrm{Ca}$ in this important disorder, we aimed in this study to increase Ca content in the Ca sink (young leaves, by foliar Ca sprays) as well as in the Ca source (bulb scales, by preplant bulb dips into calcium solution) in order to reduce ULN.

\section{Materials and Methods}

Bulbs (16-18 cm in circumference) of Lilium 'Star Gazer' were planted in $15-\mathrm{cm}$ plastic pots with a mix of 1 soil : 2 peat moss $: 1$ perlite (by volume). The following amendments $\left(\mathrm{kg} \cdot \mathrm{m}^{-3}\right)$ were added to the soil mix: dolomitic lime, 2.92; gypsum, 1.16; triple super phosphate, 0.58; Micromax (ScottsSierra Horticultural Products Co., Marysville, Ohio), 0.88 ; calcium nitrate, 0.28 ; and potassium nitrate, 0.28. Plants were forced in a greenhouse in Ithaca, N.Y., using standard cultural practice (Miller, 1992). Temperature was set to $17^{\circ} \mathrm{C}$ day $/ 17^{\circ} \mathrm{C}$ night. Plants were fertigated with $15 \mathrm{~N}-2.2 \mathrm{P}-12.5 \mathrm{~K}$ fertilizer (Excel 15-5-15, Scotts-Sierra) at a concentration of $200 \mathrm{mg} \cdot \mathrm{L}^{-1} \mathrm{~N}$ during the experiment. Calcium concentration in the fertilizer solution was $67 \mathrm{mg} \cdot \mathrm{L}^{-1}$.

The incidence of ULN occurrence was defined as the percentage of plants that had any level of symptom expression. When the environment is not conducive to ULN occurrence, incidence is a good enough parameter to distinguish differences between treatments. However, in ULN-favorable environments, ULN occurrence is widespread, but plants exhibit a large variation in severity. Therefore, a more detailed parameter, "ULN severity," is needed, in order to further refine differences 
among treatments. An index from 0 to 5, based on symptom progression and necrosed leaf area, was used to describe the severity of necrosis on individual leaves: $0=$ no visible necrosis symptoms; $1=$ chlorotic spots; $2=$ curled leaf margin; $3=$ marginal necrosis; 4 $=$ dead leaf tip; and $5=>50 \%$ of the leaf area was necrotic. We have previously demonstrated that leaf $\mathrm{Ca}$ concentration is negatively correlated with necrosed leaf area (i.e., single leaf severity index) (Chang, 2002). The severities of the individual leaves were then summed to determine whole-plant severity. Since a ULNaffected plant may have only one leaf with very slight symptoms, or have many leaves with severe necrosis, in this study whole-plant severity is a better descriptor than necrosis incidence when the environment is favorable to ULN. When whole-plant severity was $<5$, the symptoms were very light, and would not draw the consumers' attention. This index system was also adapted to describe the phytotoxicity symptoms of leaf tip yellowing caused by high concentrations of Ca salts.

Foliar sprays of calcium salts. Three experiments were conducted to determine the effect of foliar Ca sprays. Two (reagent grade) Ca salts, calcium chloride $\left(\mathrm{CaCl}_{2} \cdot 2 \mathrm{H}_{2} \mathrm{O}\right)$ and calcium nitrate $\left(\mathrm{Ca}\left(\mathrm{NO}_{3}\right)_{2} \cdot 4 \mathrm{H}_{2} \mathrm{O}\right)$, were used. Salts were dissolved in distilled water and $0.1 \%$ surfactant (Tween 20, Sigma Chemical Co., St. Louis) was added. Plants were sprayed with $\mathrm{Ca}$ solution to runoff, and controls received water plus surfactant. Each plant received $\approx 20 \mathrm{~mL}$ of solution. Experiment 1 began on 4 Dec.; the average bulb fresh weight was $66.3 \pm 0.4 \mathrm{~g}$. Five concentrations, 0, 10, 50, 100, and 150 $\mathrm{mm}$ of calcium chloride or calcium nitrate were used, with a total of five sprays applied at 15, $18,22,25$, and $29 \mathrm{~d}$ after planting (DAP). Each treatment had 18 single-plant replicates in a completely randomized design (CRD).

Experiment 2 began 27 Jan., using bulbs with an average fresh weight of $69.2 \pm 0.5 \mathrm{~g}$. Calcium chloride and calcium nitrate were used at concentrations of $0,25,50,100$, and $150 \mathrm{~mm}$ and application frequency was once per day. Besides spraying to runoff, extra $\mathrm{Ca}$ solution, $\approx 5 \mathrm{~mL}$, was sprayed directly toward the shoot apex in order to have the solution reach young, folded leaves. Each treatment had 18 single-plant replicates in a CRD. A total of 14 sprays was applied daily from 22 to 35 DAP.

Experiment 3 began 30 May with bulbs weighing $65.5 \pm 0.5 \mathrm{~g}$. Treatments included 0 , $12.5,25,50$ mmcalcium chloride and calcium nitrate with extra spraying into the apex (as described above), and $50 \mathrm{mmwithout} \mathrm{the} \mathrm{extra}$ directed spray. Application frequency was once a day for $14 \mathrm{~d}$ (30-43 DAP). Each treatment had 18 single plant replicates in a CRD.

Calcium chloride bulb dips. Two experiments were conducted to evaluate the efficacy of bulb Ca dips for preventing upper leaf necrosis. On 18 Oct., uniform bulbs $(61.8 \pm$ $0.4 \mathrm{~g})$ were randomly selected and weighed (a process taking $\approx 4 \mathrm{~h}$ at room temperature). Bulbs were then dipped in calcium chloride solution for $15 \mathrm{~min}$, with concentrations of $0,25,50,100,200$, and $400 \mathrm{~mm}$. The dipped bulbs were allowed to dry at $3{ }^{\circ} \mathrm{C}$ overnight and planted on 19 Oct. In the second experiment, three Ca concentrations $(0,200$, and 400 $\mathrm{mm}$, from calcium chloride) were tested, with dipping times of $0,1,4$, or $16 \mathrm{~h}$. Bulbs (weighing $68.7 \pm 0.4 \mathrm{~g}$ ) were randomly selected and divided into seven groups to receive treatments, a process taking $\approx 7 \mathrm{~h}$ and causing a water loss of $3 \mathrm{~g}$ per bulb (on average, based on 56 bulbs). After dipping, excess solution was allowed to runoff for $30 \mathrm{~min}$; then bulbs were reweighed. Solution absorption per bulb was calculated as: fresh weight after dipping - initial fresh weight $+3 \mathrm{~g}$ (for water loss during the process). Dipping was conducted 9 July and bulbs planted 10 July.

In both experiments, a CRD was used. There were 32 single-plant replicates per treatment for the first experiment, and 28 for the second. Distilled water was used to make the solutions and $0.1 \%$ Tween 20 was added as a wetting agent.

Statistical analysis. All statistical tests were conducted using SAS version 8.01 (SAS Institute, Cary, N.C.). Incidence of ULN, calcium phytotoxicity, and lethal calcium damage were tested using the chi-square test of independence, and ULN severity was tested using one-way analysis of variance (ANOVA). Duncan's multiple range test tested for differences among treatment means. Because the levels of the independent variables (calcium concentration and dipping time) are in fact numerical, we additionally tested for trends in
ULN severity and phytotoxicity severity using linear regression. Results are only presented for phytotoxicity as no trends were evident for ULN severity (all $R^{2} \leq 0.20$ ).

\section{Results}

Effect of foliar calcium sprays. In the first foliar Ca spray experiment, with a spray frequency of twice a week, no effects on ULN were observed, even when the Ca concentration was as high as $150 \mathrm{~mm}$ (Table 1). In the second and third experiments, with 14 daily sprays, both calcium salts were effective for reducing the degree of symptom expression (Tables 2 and 3). Experiment 2 was done in a drier greenhouse and the plants were lightly affected by ULN. When ULN was light, both calcium chloride and calcium nitrate were able to reduce ULN incidence in a concentrationdependent manner (Table 2). When ULN was severe, 14 daily foliar Ca sprays significantly reduced ULN severity to an acceptable level (whole-plant severity $<5$, which would not be noticed by consumers) (Fig. 1 and Table 3).

Both calcium chloride and calcium nitrate were effective, and there was no notable difference in the effectiveness of these two salts (Tables 2 and 3). However, increased concentrations of both salts caused higher severity of yellowing and browning injury on leaf tips (Table 2). Mean comparisons indicated that at concentrations of 100 and $150 \mathrm{~mm}$, calcium chloride was more phytotoxic than calcium

Table 1. Effectiveness of bi-weekly foliar calcium sprays for reducing upper leaf necrosis on Lilium 'Star Gazer' $(\mathrm{n}=18)$.

\begin{tabular}{lccr}
\hline & Concn & \multicolumn{2}{c}{ Necrosis } \\
\cline { 3 - 4 } Calcium salt & $(\mathrm{mm})$ & Incidence $(\%)$ & Severity \\
\hline Control & & 83.3 & $7.9 \mathrm{a}^{2}$ \\
$\mathrm{CaCl}_{2} \cdot 2 \mathrm{H}_{2} \mathrm{O}$ & 10 & $83.3^{\text {ss }}$ & $7.9 \mathrm{a}$ \\
& 50 & $83.3^{\text {Ns }}$ & $10.7 \mathrm{a}$ \\
& 100 & $83.3^{\text {ss }}$ & $7.6 \mathrm{a}$ \\
$\mathrm{Ca}\left(\mathrm{NO}_{3}\right)_{2} \cdot 4 \mathrm{H}_{2} \mathrm{O}$ & 150 & $100.0^{\text {ss }}$ & $10.6 \mathrm{a}$ \\
& 10 & $83.3^{\text {ss }}$ & $7.1 \mathrm{a}$ \\
& 50 & $100.0^{\text {ss }}$ & $6.2 \mathrm{a}$ \\
& 100 & $100.0^{\text {ss }}$ & $10.4 \mathrm{a}$ \\
& 150 & $83.3^{\text {ss }}$ & $7.2 \mathrm{a}$ \\
\hline
\end{tabular}

${ }^{2}$ Means followed by a different letter are significantly different at $P \leq 0.05$ by Duncan's multiple range test.

${ }^{\text {Ns }}$ Nonsignificant at $P \leq 0.05$ compared to control by chi-square test.

Table 2. Effectiveness and salt toxicity of daily foliar calcium sprays on upper leaf necrosis in Lilium 'Star Gazer' $(\mathrm{n}=18)$.

\begin{tabular}{lcccccr}
\hline & Concn & \multicolumn{2}{c}{ Necrosis } & & \multicolumn{2}{c}{ Phytotoxicity } \\
\cline { 3 - 4 } \cline { 6 - 7 } Calcium salt & $(\mathrm{mm})$ & Incidence $(\%)$ & Severity & & Incidence $(\%)$ & Severity \\
\hline $\mathrm{Control}$ & & 50.0 & $0.4 \mathrm{ab}^{2}$ & & 0.0 & $0.0 \mathrm{~d}^{\mathrm{y}}$ \\
$\mathrm{CaCl}_{2} \cdot 2 \mathrm{H}_{2} \mathrm{O}$ & 25 & $11.1^{*}$ & $0.2 \mathrm{~b}$ & & $33.3^{* *}$ & $1.2 \mathrm{~d}$ \\
& 50 & $33.3^{\text {ss }}$ & $0.8 \mathrm{a}$ & & $94.4^{* *}$ & $4.2 \mathrm{~d}$ \\
& 100 & $11.1^{*}$ & $0.1 \mathrm{~b}$ & & $100.0^{* *}$ & $20.0 \mathrm{~b}$ \\
& 150 & $0.0^{* * *}$ & $0.0 \mathrm{~b}$ & & $100.0^{* *}$ & $31.4 \mathrm{a}$ \\
$\mathrm{Ca}\left(\mathrm{NO}_{3}\right)_{2} \cdot 4 \mathrm{H}_{2} \mathrm{O}$ & 25 & $22.2^{\text {ss }}$ & $0.1 \mathrm{~b}$ & & $38.9^{* *}$ & $0.6 \mathrm{~d}$ \\
& 50 & $22.2^{\text {ss }}$ & $0.5 \mathrm{ab}$ & & $66.7^{* *}$ & $3.1 \mathrm{~d}$ \\
& 100 & $11.1^{*}$ & $0.2 \mathrm{~b}$ & & $100.0^{* * *}$ & $9.2 \mathrm{c}$ \\
& 150 & $16.7^{*}$ & $0.2 \mathrm{~b}$ & & $100.0^{* *}$ & $21.2 \mathrm{~b}$ \\
\hline
\end{tabular}

${ }^{ }$Means followed by a different letter are significantly different at $P \leq 0.05$ by Duncan's multiple range test.

${ }^{y}$ Linear regression equation for calcium concentration vs. phytotoxicity severity for $\mathrm{CaCl}_{2} \cdot 2 \mathrm{H}_{2} \mathrm{O}$ : $\mathrm{y}=-3.3+0.225 \mathrm{x}$, significant at $P \leq 0.0001$; for $\mathrm{Ca}\left(\mathrm{NO}_{3}\right)_{2} \cdot 4 \mathrm{H}_{2} \mathrm{O}: \mathrm{y}=-2.4+0.142 \mathrm{x}$, significant at $P \leq 0.0001$.

Ns, *, "*Nonsignificant or significant at $P \leq 0.05$ and 0.01 , respectively, compared to control by chisquare test. 


\section{Soll Management, Fertilization, \& Irrigation}

Table 3. Effectiveness of daily foliar calcium sprays and shoot apex directed sprays on upper leaf necrosis in Lilium 'Star Gazer' $(\mathrm{n}=18)$.

\begin{tabular}{llcr}
\hline & \multicolumn{1}{c}{$\begin{array}{c}\text { Concn } \\
\text { Calcium salt }\end{array}$} & \multicolumn{2}{c}{ Necrosis } \\
\cline { 3 - 4 } $\mathrm{Control}^{\mathrm{z}}$ & & Incidence $(\%)$ & Severity \\
$\mathrm{CaCl}_{2} \cdot 2 \mathrm{H}_{2} \mathrm{O}$ & 12.5 & 77.8 & $18.0 \mathrm{a}^{\mathrm{y}}$ \\
& 25 & $61.1^{\mathrm{Ns}}$ & $3.5 \mathrm{c}$ \\
& 50 & $55.6^{\mathrm{Ns}}$ & $2.7 \mathrm{c}$ \\
$\mathrm{Ca}\left(\mathrm{NO}_{3}\right)_{2} \cdot 4 \mathrm{H}_{2} \mathrm{O}$ & 50, no directed spray & $77.8^{\mathrm{Ns}}$ & $2.9 \mathrm{c}$ \\
& 12.5 & $66.7^{\mathrm{Ns}}$ & $11.7 \mathrm{~b}$ \\
& 25 & $55.6^{\mathrm{Ns}}$ & $4.5 \mathrm{c}$ \\
& 50 & $72.2^{\mathrm{Ns}}$ & $2.0 \mathrm{c}$ \\
& 50, no directed spray & $72.2^{\mathrm{Ns}}$ & $2.6 \mathrm{c}$ \\
\hline
\end{tabular}

${ }^{2}$ Ca solution was sprayed to runoff and extra solution, $\approx 5 \mathrm{~mL}$, was sprayed directly toward the shoot apex unless otherwise noted.

${ }^{y}$ Means followed by a different letter are significantly different at $P \leq 0.05$ by Duncan's multiple range test.

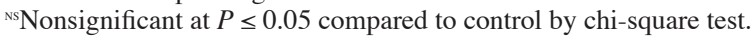

Table 4. Effectiveness of a 15-min bulb dip in calcium chloride on upper leaf necrosis on Lilium 'Star Gazer' $(\mathrm{n}=32)$.

\begin{tabular}{lcc}
\hline & \multicolumn{2}{c}{ Necrosis } \\
\cline { 2 - 3 } Concn $(\mathrm{mm})$ & Incidence $(\%)$ & Severity \\
\hline 0 (Control) & 100.0 & $15.5 \mathrm{a}^{\mathrm{z}}$ \\
25 & $100.0^{\mathrm{Ns}}$ & $15.9 \mathrm{a}$ \\
50 & $93.8^{\mathrm{Ns}}$ & $15.5 \mathrm{a}$ \\
100 & $100.0^{\mathrm{Ns}}$ & $14.3 \mathrm{ab}$ \\
200 & $87.5^{*}$ & $11.6 \mathrm{ab}$ \\
400 & $93.8^{\mathrm{Ns}}$ & $10.7 \mathrm{~b}$ \\
\hline
\end{tabular}

${ }^{\mathrm{z}}$ Means followed by a different letter are significantly different at $P \leq 0.05$ by Duncan's multiple range test.

Ns," Nonsignificant or significant at $P \leq 0.05$ compared to control by chi-square test.

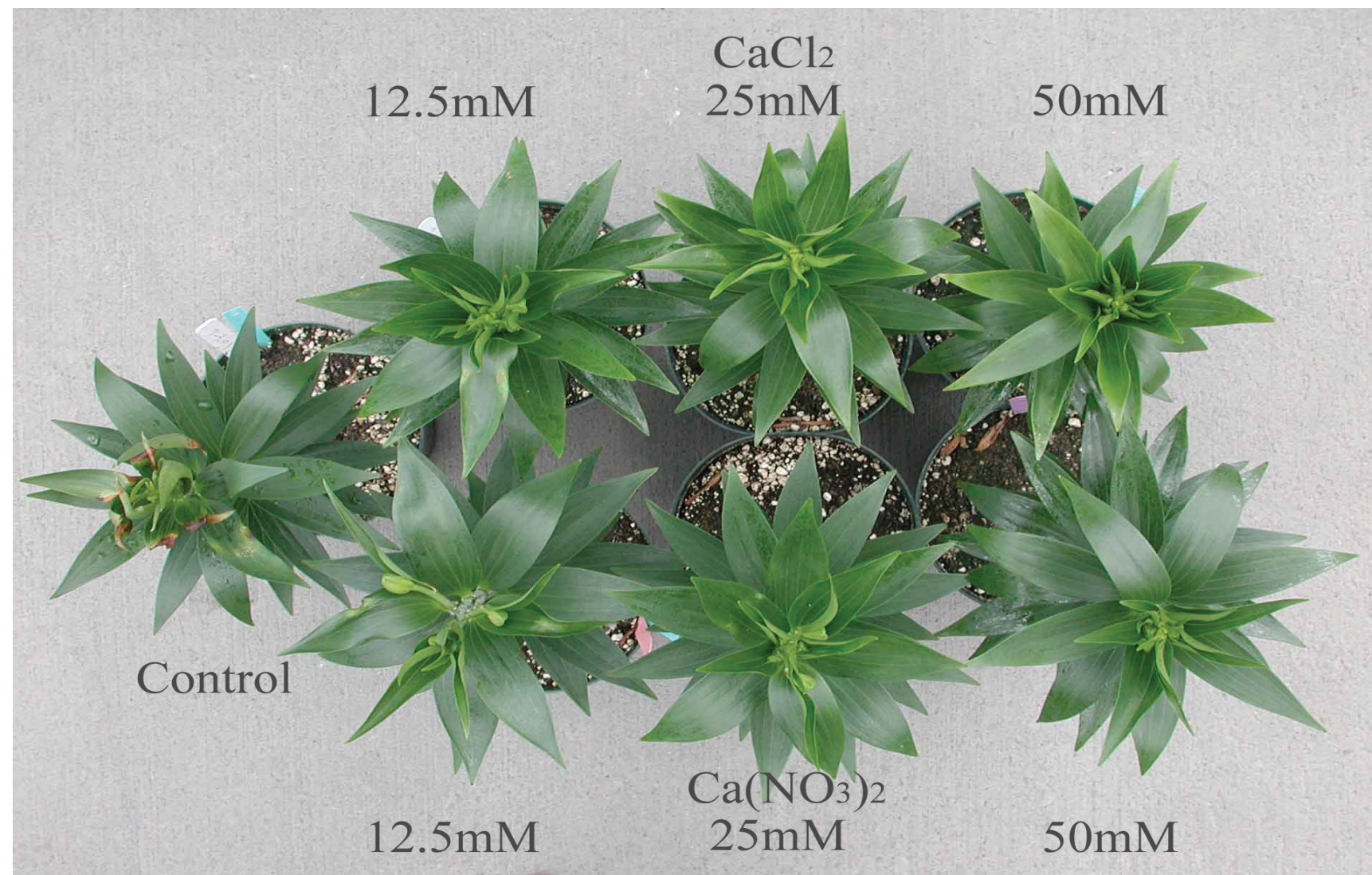

Fig. 1. Effect of 14 daily foliar calcium sprays on reducing upper leaf necrosis on Lilium 'Star Gazer': (left) control; (top) calcium chloride treatments; and (bottom) calcium nitrate treatments.

nitrate (Table 2). Thus, single daily foliar sprays of $25 \mathrm{~mm}$ calcium chloride or calcium nitrate for $14 \mathrm{~d}$ were safe and effective for reducing the risk of ULN (Tables 2 and 3).

The marginal effectiveness of the additional directed spray depended on the calcium salt used. With calcium nitrate, the extra spray had little effect. With calcium chloride, the 50-mm directed spray gave a further reduction in ULN severity as compared to $50 \mathrm{mmCa}$ without the directed spray (Table 3). Without the extra directed spray, the effect of $50 \mathrm{~mm}$ calcium chloride was even less than that of 12.5 mmwith directed spray. Ensuring Ca solution reached enclosed leaves was thus imperative for foliar Ca sprays to be effective (Table 3 ).

Effect of bulb calcium dipping. Solution uptake by bulbs depended on the concentra- tion and the dipping time (Table 5). Bulbs in the control group absorbed significantly more solution than in other treatments. After dipping in water for $16 \mathrm{~h}$ (control group), each bulb absorbed $\approx 5 \mathrm{~mL}$ solution. As concentration increased, less solution was absorbed by the bulb. In the 200-mm treatments, longer dipping time resulted in greater solution uptake (Table 5).

In both experiments, dipping bulbs in calcium chloride had no effect on ULN incidence. All dipping treatments had a ULN incidence greater than $81 \%$, compared to the controls with $100 \%$ or $93 \%$ (Tables 4 and 5). In the first experiment, in which bulbs were dipped in calcium chloride solution for $15 \mathrm{~min}$, ULN severity was slightly reduced at higher concentrations (200 and $400 \mathrm{~mm}$ ). Controls had an average severity of 15.5 , vs. 10.7 in the 400-mmtreatment (Table 4). In the second experiment, however, there was no significant effect, even with much longer dipping times (Table 5).

Phytotoxicity was seen on young shoots due to high concentration of calcium chloride in the 4- or 16-h dips. These treatments proved fatal up to $11 \%$ of the plants, which died in early development stages (Table 5).

\section{Discussion}

The effectiveness of foliar Ca sprays to reduce the risk of $\mathrm{Ca}$ deficiency disorders has been controversial. Calcium sprays were effective in reducing marginal bract necrosis on poinsettia (Wissemeier, 1993) and tipburn 
Table 5. Effects of calcium chloride concentration and length of bulb dip on upper leaf necrosis on Lilium 'Star Gazer' $(\mathrm{n}=28)$.

\begin{tabular}{|c|c|c|c|c|c|}
\hline \multirow{2}{*}{$\begin{array}{l}\text { Concn } \\
(\mathrm{mm})\end{array}$} & \multirow{2}{*}{$\begin{array}{l}\text { Dipping time } \\
\text { (h) }\end{array}$} & \multirow{2}{*}{$\begin{array}{l}\text { Solution absorbed } \\
\qquad(\mathrm{mL})\end{array}$} & \multicolumn{2}{|c|}{ Necrosis } & \multirow{2}{*}{$\begin{array}{c}\text { Lethal calcium } \\
\text { damage }(\%)\end{array}$} \\
\hline & & & Incidence $(\%)$ & Severity & \\
\hline 0 & 16 & $5.3 \mathrm{a}^{\mathrm{z}}$ & 92.9 & $12.8 \mathrm{a}$ & 0.0 \\
\hline 200 & 1 & $2.0 \mathrm{~d}$ & $92.9^{\mathrm{Ns}}$ & $12.3 \mathrm{a}$ & $0.0^{\mathrm{Ns}}$ \\
\hline 200 & 4 & $2.7 \mathrm{c}$ & $100.0^{\mathrm{Ns}}$ & $14.2 \mathrm{a}$ & $3.6^{\mathrm{Ns}}$ \\
\hline 200 & 16 & $3.4 \mathrm{~b}$ & $81.5^{\mathrm{Ns}}$ & $12.3 \mathrm{a}$ & $0.0^{\mathrm{Ns}}$ \\
\hline 400 & 1 & $1.9 \mathrm{de}$ & $92.9^{\mathrm{Ns}}$ & $13.2 \mathrm{a}$ & $0.0^{\mathrm{Ns}}$ \\
\hline 400 & 4 & $2.0 \mathrm{~d}$ & $85.2^{\mathrm{Ns}}$ & $14.0 \mathrm{a}$ & $3.6^{\mathrm{Ns}}$ \\
\hline 400 & 16 & $1.6 \mathrm{e}$ & $84.0^{\mathrm{Ns}}$ & $12.7 \mathrm{a}$ & $10.7^{\mathrm{Ns}}$ \\
\hline
\end{tabular}

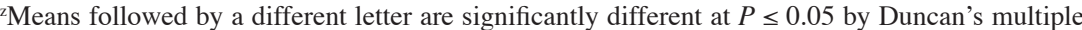
range test.

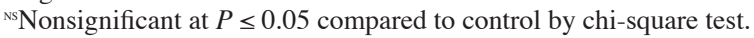

on the Asiatic hybrid lily 'Pirate' (Berghoef, 1986). With lettuce, researchers have reached differing conclusions on the utility of foliar sprays in reducing leaf tipburn: Some researchers show positive results of Ca sprays (Kruger, 1966; Thibodeau and Minotti, 1969), while others report no effect (Collier and Tibbitts, 1982; Misaghi et al., 1981). The contrasting results may be attributed to genetic variation, Ca salt, Ca concentration, application timing, and frequency.

In this study, we demonstrated that 14 daily foliar sprays of $25 \mathrm{~mm}$ calcium chloride or calcium nitrate are effective in reducing the risk of ULN, and efficacy was improved by directing $\mathrm{Ca}$ to the enclosed leaves (Table 3). Calcium is an immobile nutrient element that is translocated mainly in the xylem. It is well established that $\mathrm{Ca}$ does not move from old leaves to young ones (Kirkby and Pilbeam, 1984; Marschner, 1995). Symptoms of ULN develop only on young expanding upper leaves (Chang, 2002), and expanding leaves are known to have a high calcium demand (Collier and Tibbitts, 1982; Kirkby and Pilbeam, 1984). Therefore, it is understandable that applying Ca to foliage twice a week didn't reduce ULN (Table 1), since it could not meet the high demands of rapidly growing leaves. In tipburn of Asiatic lily 'Pirate,' it was reported a single Ca spray was not effective (van Nes, 1978), but daily sprays were (Berghoef, 1986; Berghoef et al., 1981). When calcium hydroxide was applied to reduce rain splitting in sweet cherries, multiple sprays gave better protection than a single spray (Meheriuk et al., 1991). Since the lower leaves are not susceptible to ULN (Chang, 2002), it is not necessary to spray calcium onto the lower leaves.

In foliar Ca spray experiments, there was no difference in the effectiveness of the two calcium salts used (Tables 2 and 3). Similar results were seen with calcium applications to control bitter bit in apple (Sharples and
Little, 1970). However, it was reported that calcium nitrate seemed to be less effective than calcium chloride for reducing tipburn on 'Pirate' lily (Berghoef et al., 1981). With daily foliar sprays at $\mathrm{Ca}$ concentrations of 100 and $150 \mathrm{~mm}$, phytotoxicity, in the form of leaf tip yellowing, was observed. Similar toxicity from foliar Ca sprays was also observed on Asiatic hybrid lily 'Pirate' (Berghoef, 1986) and apple (Sharples and Little, 1970).

Dipping bulbs in calcium chloride failed to control ULN. In the first experiment, dipping bulbs in $400 \mathrm{mmCaCl} \cdot 2 \mathrm{H}_{2} \mathrm{O}$ for $15 \mathrm{~min}$ reduced ULN severity from 15.5 to 10.7 (Table 4). However, the same trend was not observed in the second experiment (Table 5). Since bulbs were immersed in calcium chloride for a longer time in the second experiment, we concluded bulb $\mathrm{Ca}$ dipping is not a feasible method to solve the problem. Similarly, 24-h bulb soaks in 136 or 272 mmcalcium chloride showed no positive effects on Asiatic hybrid lily 'Pirate' (Berghoef, 1986).

The effects of applying Ca to young leaves and to bulbs in order to reduce ULN were completely different. Bulb $\mathrm{Ca}$ dipping was not effective, but some foliar $\mathrm{Ca}$ treatments were. It is understandable that spraying $\mathrm{Ca}$ directly to young expanding leaves was effective to reduce ULN and other Ca deficiency disorders, since mineral nutrient entry could occur through cuticular pores (Marschner, 1995) or stomatal openings (Levy and Horesh, 1984).

As a result of this research, growers interested in using calcium foliar sprays to reduce this problem could be advised to spray calcium nitrate or calcium chloride at no more than $25 \mathrm{~mm}$ daily, for $14 \mathrm{~d}$ starting 30 DAP. Furthermore, an effort to direct spray into the congested leaves should be made. Whether or not this is an economically viable treatment would need to be determined by the individual grower.

\section{Literature Cited}

Berghoef, J. 1986. Effect of calcium on tipburn of Lilium 'Pirate'. Acta Hort. 177:433-438.

Berghoef, J., G.S.J. Kappelhof, and B. Willems. 1981. Control of leaf scorch on lilies, cv. Pirate, requires further research. Vakblad voor de Bloemisterij 36:22-23.

Chang, Y.C. 2002. Upper leaf necrosis on Lilium cv. Star Gazer-Acalcium deficiency disorder. $\mathrm{PhD}$ Diss., Cornell Univ., Ithaca, N.Y. Diss. Abstr. Intl. 63-09B:4077.

Chang, Y.C. and W.B. Miller. 2003. Growth and calcium partitioning in Lilium 'Star Gazer' in relation to leaf calcium deficiency. J. Amer. Soc. Hort. Sci. 128:788-796.

Chang, Y.C. and W.B. Miller. 2004. The relationship between leaf enclosure, transpiration, and upper leaf necrosis on Lilium 'Star Gazer'. J. Amer. Soc. Hort. Sci. 129:128-133.

Collier, G.F. and T.W. Tibbitts. 1982. Tipburn of lettuce. Hort. Rev. 4:49-65.

Ferguson, I.B. and C.B. Watkins. 1989. Bitter pit in apple fruit. Hort. Rev. 11:289-355.

Kirkby, E.A. and D.J. Pilbeam. 1984. Calcium as a plant nutrient. Plant Cell Environ. 7:397-405.

Kruger, N.S. 1966. Tipburn of lettuce in relation to calcium nutrition. Queensland J. Agr. Animal Sci. 23:379-385.

Levy, Y. and I. Horesh. 1984. Importance of penetration through stomata in the correction of chlorosis with iron salts and low-surface-tension surfactants. J. Plant Nutr. 7:279-281.

Marschner, H. 1995. Mineral nutrition of higher plants. Academic Press, London, U.K.

Meheriuk, M., G.H. Neilsen, and D.L. McKenzie. 1991. Incidence of rain splitting in sweet cherries treated with calcium or coating materials. Can. J. Plant Sci. 71:231-234.

Miller, W.B. 1992. Easter and hybrid lily production-Principles and practice. Timber Press, Portland, Ore.

Misaghi, I.J., C.A. Matyac, and R.G. Grogan. 1981. Soil and foliar applications of calcium chloride and calcium nitrate to control tipburn of head lettuce. Plant Dis. 65:821-822.

Ranwala, A.P., G. Legnani, M. Reitmeier, B.B. Stewart, and W.B. Miller. 2002. Efficacy of plant growth retardants as preplant bulb dips for height control in LA and Oriental hybrid lilies. HortTechnology 12:426-431.

Sharples, R.O. and R.C. Little. 1970. Experiments on the use of calcium sprays for bitter pit control in apples. J. Hort. Sci. 45:49-56.

Thibodeau,P.O. and P.L. Minotti. 1969. The influence of calcium on the development of lettuce tipburn. J. Amer. Soc. Hort. Sci. 94:372-376.

van Berkel, N. 1988. Preventing tipburn in Chinese cabbage by high relative humidity during the night. Neth. J. Agr. Sci. 36:301-308.

van Nes, I.C. 1978. Bladverbranding bij leliecultivar 'Pirate'. Bloemisterij Oderzoek in Nederland 1978:182-187.

Wissemeier, A.H. 1993. Marginal bract necrosis in poinsettia cultivars and the relationship to bract calcium nutrition. Gartenbauwissenschaft 58:158-163. 